\title{
SOCIODEMOGRAPHIC AND CLINICAL CHARACTERIZATION OF PATIENTS WITH VASCULOGENIC ULCERS
}

\author{
CARACTERIZAÇÃO SOCIODEMOGRÁFICA E CLÍNICA DE PACIENTES \\ COM ÚLCERAS VASCULOGÊNICAS
}

\begin{abstract}
Sarah Nilkece Mesquita ARAUJO' ${ }^{\text {; }}$ Lydia Tosltenko NOGUEIRA $^{2}$; Maria do Livramento Fortes FIGUEIREDO ${ }^{3}$; Elaine Maria Leite rangel ANDRADE ${ }^{4}$; Roberta Fortes SANTIAGO ${ }^{5}$; Ana Beatriz da rocha SILVA ${ }^{6}$; Felipe dos Santos CARDOSO ${ }^{7}$

1. Enfermeira, Doutoranda em Enfermagem, Universidade Federal do Piauí-UFPI, Teresina, PI, Brasil. sarahnilkece@hotmail.com; 2. Enfermeira, Doutora em Enfermagem, Professora do Programa de pós-graduação em Enfermagem, Universidade Federal do Piauí-UFPI, Teresina, PI, Brasil; 3. Enfermeira, Doutora em Enfermagem, Professora do Programa de pósgraduação em Enfermagem, Universidade Federal do Piauí-UFPI, Teresina, PI, Brasil; 4. Enfermeira, Doutora em Enfermagem, Professora do Programa de pós-graduação em Enfermagem, Universidade Federal do Piauí-UFPI, Teresina, PI, Brasil; 5. Enfermeira, Doutoranda em Enfermagem, Universidade Federal do Piauí-UFPI, Teresina, PI, Brasil; 6. Enfermeira, Associação de Ensino Superior do Piauí - AESPI, Teresina, PI, Brasil; 7. Enfermeiro, Associação de Ensino Superior do Piauí - AESPI, Teresina, PI, Brasil.
\end{abstract}

\begin{abstract}
Vasculogenic ulcers may be of arterial, venous or arteriovenous (mixed) origin and compromise the dermis and epidermis, and may also affect deeper tissues, characterized by a chronic, painful and slow healing process, which impacts the quality of life and in the mental, physical and social aspects of the affected persons, thus leading them to the total dependence of the health service. The objective was to characterize the sociodemographic and clinical profile of patients with vasculogenic ulcers. This is a cross-sectional descriptive study developed at the Surgical Clinic in an Emergency Hospital in the Northeastern region of Brazil, with 38 patients with vasculogenic ulcers, from September to October 2016. Data were collected in patients' records and confirmed by interview. As a result of the sociodemographic profile, the majority were male (55.3\%), brown $(55.3 \%)$, elderly and adult (50\%, each), married (50\%), with income up to a minimum wage $(81.6 \%)$, retirees $(55.3 \%)$, attended the elementary school $(57.9 \%)$ and all were from the Northeastern region of Brazil. Clinically, 34.2\% had peripheral angiopathy, venous ulcers (50\%), Arterial Hypertension and Diabetes Melitus (50\%). The most frequent surgical procedure was amputation of the limb affected by the ulcer (55.3\%). Knowing the profile of the clientele is fundamental for making better decisions and defining a clinical reasoning more appropriate to patients, which should be conducted in a comprehensive manner by the nursing team.
\end{abstract}

KEYWORDS: Vasculogenic ulcers. Wounds. Nursing.

\section{INTRODUCTION}

Vasculogenic ulcers may be of arterial, venous or arteriovenous (mixed) origin and compromise the dermis and epidermis, and may also affect deeper tissues, characterized by a chronic, painful and slow healing process, which impacts the quality of life and in the mental, physical and social aspects of the affected persons, thus leading them to the total dependence of the health service. These lesions compromise the lower limbs and affect, mainly, the leg, foot and toe-to-toe (MALAQUIAS et al, 2012).

Among the general causes of vasculogenic ulcers are valvular insufficiency, venous obstruction, neuropathies and arterial ischemia. Leg ulcers, as they are also called vasculogenic lesions, develop from an insufficiency in the arterial, venous or both flow, causing partial or total loss of skin thickness (SILVA ; HANH, 2012).

In Brazil, it is estimated that $3 \%$ of the population has vasculogence lesions, including the 14th cause of provisional removal and the 32nd cause of absolute separation from the labor market, which generates a significant socioeconomic impact (FIGUEIREDO; ZUFFI, 2012). The incidence is $5.9 \%$ in industrialized countries. In the United States, more than 7 million people are affected by this condition, and wounds occur in more than 2.5 million patients a year, a major cause of morbidity and a decline in quality of life. With regard to the cost of treatment of chronic ulcers in lower limbs per patient, it is estimated to be approximately $\$$ 30,000 per year in the US, which represents $1 \%$ of the health budget (O'DONNELL; LAU, 2006).

Due to the difficulty of diagnostic differentiation between arterial, venous and mixed lesions, there is doubtful notification of the incidence of these lesions, but on average studies suggest a representation of $75 \%$ for venous and 10 to $25 \%$ for arterial and arteriovenous lesions. Other studies point to the incidence of venous ulcers, corresponding 70 to $90 \%$ of the total, and the most important etiological factor is venous insufficiency, which due to valvular deficiency causes inefficient return and / or blood flow through vessel 
obstruction. These lesions are commonly related to the elderly and female, with the proportion of women to men being 3/1 (BUSO et al, 2016; SILVA; HANH, 2012).

The nursing care for the patient with a vasculogenic ulcer should be based on knowledge not only of the anatomy of the lesion but also of the underlying disease and its implications. The healing of these lesions is a dynamic, continuous and complex process and that several factors can harm it by slowing the restoration of the skin. Among the intervening factors of healing are infection, low tissue perfusion, radiotherapy, chemical agents, nutritional alterations, obesity, inadequate dressing technique, chronic diseases such as Diabetes Mellitus (DM), therefore it is necessary to fully understand the patient to reduce action of these factors (OLIVEIRA et al, 2013).

Making the patient feel co-responsible for their health and their treatment, acting actively in decision-making and goal setting, will promote significant changes for better adherence to the proposed care. Emphasis is placed on the role of the nurse in motivating the patient, promoting individual care in order to improve their living conditions. The patient is perceived as a human being, possessing biological, psychological, social and spiritual needs. Patient care actions with vasculogenic ulcers should be provided effectively, focusing on the patient's comprehensiveness and not only on skin lesion (TEIXEIRA; SILVA, 2016).

Understanding the sociodemographic and clinical characteristics of patients with vasculogenic lesions is fundamental for more organized and individualized care planning. Therefore, this study is justified by providing greater knowledge of this clientele, with a view to improving the assistance of primary to more complex levels to patients with vasculogenic lesions.

Thus, the objective of this study was to characterize the sociodemographic and clinical profile of patients with vasculogenic ulcers in an Emergency Hospital in the Northeast Region of Brazil.

\section{MATERIAL AND METHODS}

This is a cross-sectional descriptive study developed at the surgical clinic in an Emergency Hospital located in the Northeastern region of Brazil. The service assists urgency and emergency patients in the specialties of neurology, orthopedics, vascular, general surgery, bucomaxillofacial and others. The Surgical Clinic of this hospital is composed of 58 beds of minimum and intermediate care and admits patients of vascular surgery and other surgical specialties.

Data collection took place in September and October 2016. The study population consisted of patients with vasculogenic lesions hospitalized at the surgical clinic of the aforementioned hospital and their respective medical records. Sampling was non-probabilistic for convenience, composed of all the elements that appeared successively in the order of arrival at the service, totaling 38 patients. Included in the study patients hospitalized at the surgical clinic for indication of vascular clinic for treatment of vasculogenic injuries, adults aged 18 years and over. Five patients with cognitive limitations were excluded from the study.

The data collection instrument consisted of two parts: the first one related to the sociodemographic profile of patients with vasculogenic ulcers, with the variables: age, income, sex, schooling, occupation, naturalness and color. The second part related to the clinical profile of patients, regarding the variables: medical diagnosis, comorbidities, ulcer etiology, indicated surgical procedure, clinical complications.

For the acquisition of the data, the patients' charts were analyzed and the information that was incomplete in the medical records was complemented, through an interview with a patient, after clarifying the objectives of the study.

Data were analyzed using Statistical Package for Social Sciences (SPSS, Chicago, IL, USA), Version 20.0. A descriptive analysis of the data was performed, presenting with absolute values and percentages. Fisher's test was performed for association of patients with arterial and venous ulcers, regarding clinical and sociodemographic variables. Values of $\mathrm{p}<0.05$ were considered significant.

The project was approved by the Ethics and Research Committee of the Paulista University (UNIP), protocol number 59073816.3.0000.5512. Participants were assured of the anonymity and bioethical principles governed by Resolution 466/12.

\section{RESULTS}

The participants were 38 patients with vasculogenic ulcers, most $(55,3 \%)$ were male, married $(50,0 \%)$, with income up to a minimum wage $(81.6 \%)$, low education level $(57,9 \%)$, retired $(55,3 \%)$, from the interior of the state of Piauí $(57,9 \%)$, brown $(55,3 \%)$, adults and elderly $(50,0 \%$, each) (Table 1). 
Table 1. Sociodemographic profile of patients with vasculogenic ulcers seen in an Emergency Hospital $(\mathrm{n}=$ 38). Teresina, 2016.

\begin{tabular}{|c|c|c|}
\hline VARIABLE & $\mathbf{N}$ & $\%$ \\
\hline \multicolumn{3}{|l|}{ Sex } \\
\hline Female & 17 & 44,7 \\
\hline Male & 21 & 55,3 \\
\hline \multicolumn{3}{|l|}{ Marital status } \\
\hline Single & 10 & 26,3 \\
\hline Married & 19 & 50,0 \\
\hline Divorced & 4 & 10,5 \\
\hline Widower & 5 & 13,2 \\
\hline \multicolumn{3}{|l|}{ Monthly income } \\
\hline $1 \mathrm{MW}^{*}$ & 31 & 81,6 \\
\hline $2 \mathrm{MW}$ & 7 & 18,4 \\
\hline \multicolumn{3}{|l|}{ Level of schooling } \\
\hline Non-literate & 9 & 23,7 \\
\hline Elementary school & 22 & 57,9 \\
\hline High school & 6 & 15,8 \\
\hline Higher education & 1 & 2,6 \\
\hline \multicolumn{3}{|l|}{ Profession } \\
\hline Unemployed & 6 & 15,8 \\
\hline Employee & 11 & 28,9 \\
\hline Retired & 21 & 55,3 \\
\hline \multicolumn{3}{|l|}{ Naturalness } \\
\hline Teresina & 13 & 34,2 \\
\hline Interior of Piauí & 22 & 57,9 \\
\hline Other states & 3 & 7,9 \\
\hline \multicolumn{3}{|l|}{ Color } \\
\hline Black & 7 & 18,4 \\
\hline Brown & 21 & 55,3 \\
\hline Yellow & 5 & 13,2 \\
\hline White & 5 & 13,2 \\
\hline \multicolumn{3}{|l|}{ Age } \\
\hline 30 to 59 years & 19 & 50,0 \\
\hline 60 to 88 years & 19 & 50,0 \\
\hline Total & 38 & 100,0 \\
\hline
\end{tabular}

Legend: *MW: minimun wage; Regarding the characterization of the clinical profile, $50.0 \%$ of the patients had venous ulcers, $28.9 \%$ had arteriovenous or mixed ulcers, and $21.1 \%$ had ulcers of arterial origin (Table 2).

The most frequent medical diagnosis was peripheral angiopathy (34.2\%), followed by arterial atherosclerosis $(18.4 \%)$. With less incidence, unclassified gangrene and emboli and thrombosis of lower limb arteries were observed, both with $15.8 \%$. The simultaneous prevalence of comorbid systemic hypertension ( $\mathrm{SH})$ and diabetes mellitus (DM) was predominant in the sample $(50.0 \%)$. Amputation was the most performed surgical procedure $(55.3 \%)$ in the patients, followed by ulcer debridement $(34.2 \%)$, as shown in Table 2.

Table 3 shows the p-values of the Fisher Test results and the verifications of the possible associations between patients with arterial, venous and arteriovenous ulcers and sociodemographic variables. According to the results, an association was observed only between the type of ulcer and the color of the patient $(\mathrm{p}=0.014)$, it can be concluded that venous ulcer was more frequent in black and white and arteriovenous ulcer more frequent in yellow color.

Table 4 shows the p-values of the Fisher Test results and the verifications of the possible associations between patients with arterial, venous and mixed ulcers and clinical variables. According to the findings, an association between the ulcer type and the medical diagnosis $(p=0.001)$ was evidenced, and an association between venous ulcers and the diagnosis of peripheral angiopathy was established. 
Table 2. Clinical profile of patients with vasculogenic ulcers treated at an Urgency Hospital $(n=38)$. Teresina,

\begin{tabular}{|c|c|c|}
\hline VARIABLE & $\mathbf{N}$ & $\%$ \\
\hline \multicolumn{3}{|l|}{ Classification of Vasculogenic Ulcers } \\
\hline Venous ulcer & 19 & 50,0 \\
\hline Arteriovenous ulcer & 11 & 28,9 \\
\hline Arterial ulcer & 8 & 21,1 \\
\hline \multicolumn{3}{|l|}{ Medical diagnostic } \\
\hline Unclassified Gangrene (ICD-10 - R02) & 6 & 15,8 \\
\hline Peripheral angiopathy (ICD-10 - 179.2 & 13 & 34,2 \\
\hline Arterial atherosclerosis (ICD-10 - 170.2) & 7 & 18,4 \\
\hline Pre-diabetes (ICD-10-O24.1) & 3 & 7,9 \\
\hline Embolism and thrombosis of lower limb arteries (ICD- 10 - 174.3) & 6 & 15,8 \\
\hline $\begin{array}{l}\text { Insulin-dependent diabetes mellitus with circulatory complications(ICD-10 } \\
\text { - E10.5) }\end{array}$ & 3 & 7,9 \\
\hline \multicolumn{3}{|l|}{ Comorbidities } \\
\hline Diabetes Mellitus & 13 & 34,2 \\
\hline Systemic Arterial Hypertension & 6 & 15,8 \\
\hline Systemic Arterial Hypertension and Diabetes Mellitus & 19 & 50,0 \\
\hline \multicolumn{3}{|l|}{ Surgical procedures performed } \\
\hline Amputation & 21 & 55,3 \\
\hline Ulcer Debridement & 13 & 34,2 \\
\hline Rapprochement of previous surgery (reoperation) & 3 & 7,9 \\
\hline Abscess Drainage & 1 & 2,6 \\
\hline
\end{tabular}

Table 3. Association of patients with arterial, venous and mixed ulcers and sociodemographic variables $(\mathrm{n}=$ 38). Teresina, 2016.

\begin{tabular}{|c|c|c|c|c|}
\hline \multirow[b]{2}{*}{ VARIABLE } & \multicolumn{3}{|c|}{ ETIOLOGY OF ULCER } & \multirow[b]{2}{*}{$\begin{array}{l}\text { p-valor* } \\
(\mathbf{p}<\mathbf{0 , 0 5})\end{array}$} \\
\hline & $\begin{array}{c}\text { Arterial } \\
\text { ulcer } \\
\mathbf{N}(\%)\end{array}$ & $\begin{array}{c}\text { Venous } \\
\text { ulcer } \\
\mathbf{N}(\%)\end{array}$ & $\begin{array}{c}\text { Arteriovenous } \\
\text { ulcer } \\
\mathbf{N}(\%)\end{array}$ & \\
\hline Sex & & & & 0,822 \\
\hline Female & $4(23,5)$ & $7(41,2)$ & $6(35,3)$ & \\
\hline Male & $4(19,0)$ & $12(57,1)$ & $5(23,8)$ & \\
\hline Marital status & & & & 0,538 \\
\hline Single & $2(20,0)$ & $7(70,0)$ & $1(10,0)$ & \\
\hline Married & $4(21,1)$ & $8(42,1)$ & $7(36,8)$ & \\
\hline Divorced & $0(0,0)$ & $2(50,0)$ & $2(50,0)$ & \\
\hline Widower & $2(40,0)$ & $2(40,0)$ & $1(20,0)$ & \\
\hline Monthly income & & & & 0,865 \\
\hline $1 \mathrm{MW}^{* *}$ & $6(19,4)$ & $16(51,6)$ & $9(29,0)$ & \\
\hline $2 \mathrm{MW}$ & $2(28,6)$ & $3(42,9)$ & $2(28,6)$ & \\
\hline Schooling & & & & 0,457 \\
\hline Non-literate & $2(22,2)$ & $5(55,6)$ & $2(22,2)$ & \\
\hline Elementary school & $6(27,3)$ & $11(50,0)$ & $5(22,7)$ & \\
\hline High school & $0(0,0)$ & $0(0,0)$ & $4(66,7)$ & \\
\hline Higher education & $0(0,0)$ & $1(100,0)$ & $0(0,0)$ & \\
\hline Profession & & & & 0,108 \\
\hline Unemployed & $2(33,3)$ & $4(66,7)$ & $0(0,0)$ & \\
\hline Empolyee & $0(0,0)$ & $7(63,6)$ & $4(36,4)$ & \\
\hline Retired & $6(28,6)$ & $8(38,1)$ & $7(33,3)$ & \\
\hline Naturalness & & & & 0,238 \\
\hline Teresina & $3(23,1)$ & $4(30,8)$ & $6(46,2)$ & \\
\hline
\end{tabular}


Sociodemographic and clinical characterization...

ARAUJO, S. N. M. et al.

$\begin{array}{lccc}\text { Interior of Piaui } & 4(18,2) & 14(63,6) & 4(18,2) \\ \begin{array}{l}\text { Other states } \\ \text { Color }\end{array} & 1(33,3) & 1(33,3) & 1(33,3) \\ \text { Black } & & & \\ \text { Brown } & 0(0,0) & 5(71,4) & 2(28,6) \\ \text { Yellow } & 8(38,1) & 8(38,1) & 5(23,8) \\ \text { White } & 0(0,0) & 1(20,0) & 4(80,0) \\ \text { Age } & 0(0,0) & 5(100,0) & 0(0,0) \\ 30 \text { to 59 years } & & & \\ 60 \text { to } 88 \text { years } & 4(21,1) & 10(52,6) & 5(26,3) \\ & 4(21,1) & 9(47,4) & 6(31,6)\end{array}$

0,014

Legend: *Fisher Test; **Minimun Wage

Table 4. Association of patients with arterial and venous ulcers, regarding clinical and sociodemographic variables $(n=38)$. Teresina, 2016.

\begin{tabular}{|c|c|c|c|c|}
\hline \multirow[b]{2}{*}{ VARIABLE } & \multicolumn{3}{|c|}{$\begin{array}{l}\text { ETIOLOGY OF ULCER } \\
\end{array}$} & \multirow[b]{2}{*}{$\begin{array}{l}\text { p-valor* } \\
(\mathbf{p}<0,05)\end{array}$} \\
\hline & $\begin{array}{c}\text { Arterial } \\
\text { ulcer } \\
\text { N }(\%)\end{array}$ & $\begin{array}{c}\text { Venous } \\
\text { ulcer } \\
\mathbf{N}(\%) \\
\end{array}$ & $\begin{array}{c}\text { Arteriovenous } \\
\text { ulcer } \\
\text { N }(\%) \\
\end{array}$ & \\
\hline Medical diagnosis & & & & $\mathbf{0 , 0 0 1}$ \\
\hline Unclassified Gangrene & $0(0,0)$ & $6(100,0$ & $0(0,0)$ & \\
\hline Peripheral angiopathy & $1(7,7)$ & $11(84,6)$ & $1(7,7)$ & \\
\hline Arterial atherosclerosis & $7(100,0)$ & $0(0,0)$ & $0(0,0)$ & \\
\hline Pre-diabetic & $0(0,0)$ & $2(66,7)$ & $1(33,3)$ & \\
\hline $\begin{array}{l}\text { Embolism and thrombosis of the arteries } \\
\text { of lower limbs }\end{array}$ & $0(0,0)$ & $0(0,0)$ & $6(100,0)$ & \\
\hline $\begin{array}{l}\text { Insulin-dependent diabetes mellitus with } \\
\text { circulatory complications }\end{array}$ & $0(0,0)$ & $0(0,0)$ & $3(100,0)$ & \\
\hline Comorbidities & & & & 0,911 \\
\hline Diabetes mellitus & $2(15,4)$ & $8(61,5)$ & $3(23,1)$ & \\
\hline Arterial Hypertension & $1(16,7)$ & $3(50,0)$ & $2(33,3)$ & \\
\hline $\begin{array}{l}\text { Arterial Hypertension and diabetes } \\
\text { mellitus }\end{array}$ & $5(26,3)$ & $8(42,1)$ & $6(31,6)$ & \\
\hline Surgical procedure & & & & 0,146 \\
\hline Amputation & $3(14,3)$ & $11(52,4)$ & $7(33,3)$ & \\
\hline Debridement of Ulcer & $2(15,4)$ & $8(61,5)$ & $3(23,1)$ & \\
\hline $\begin{array}{l}\text { Rapprochement of previous surgery } \\
\text { (reoperation) }\end{array}$ & $2(66,7)$ & $0(0,0)$ & $1(33,3)$ & \\
\hline Abscess Drainage & $1(100,0)$ & $0(0,0)$ & $0(0,00$ & \\
\hline
\end{tabular}

Legend: *Fisher Test

\section{DISCUSSION}

The research sample was predominantly male, which diverges with studies that indicate a greater prevalence of vasculogenic ulcers in female patients (MALAQUIAS et al, 2012; GRIEP; CHOR.; FAERSTEIN, 2005). These data can be justified by the scenario of the study, an emergency hospital, which attends mainly cases of vasculogenic lesions with complications, often resulting from failure to follow up or lack of patients' demand for early health care, a situation more common in males, which neglects individual health preventive care.

When assessing marital status, a higher prevalence of married patients was observed. The marital relationship demonstrates a greater support to the patients when compared to the unmarried ones, contributing to a greater effectiveness in the treatment, since the support of the spouse facilitates in the cohabitation of the disease and daily care, minimizing complications (MEDEIROS et al, 2016).

The findings showed that the patients had low income. The link between low family income 
and a lower organization of the health care process and a discontinuity of treatment due to low purchasing power are evidenced. It is worth noting that the Brazilian public health system, predicting these social inequities, provides inputs, as materials for the dressing and medicines to attend this clientele, however, when there is a need for other products not available through the public network, the risk of treatment being discontinued is increased in low-income families (CARDOZO et al, 2012; GONZÁLEZ-CONSUEGRA; VERDÚ, 2011).

As with income, patients also had a low educational profile. Schooling is a point of paramount importance in care, since the lower the patient's cognition, more individual guidance measures of self-care are necessary to improve understanding of their health-disease process. For this, it is necessary that the nursing team pay attention to transmit information in a more understandable way, explaining the factors that interfere in the cicatrization in the lesions and improvement of life habits (OLIVEIRA et al, 2013).

It is crucial that nurses and staff actively develop teaching-learning methods that will lead patients with vasculogenic ulcers to gain an insight into their recovery process and control factors that contribute to healing, such as diet, control of blood pressure, blood glucose, and other physiological factors (BUSO et al, 2016).

Most of the patients were retired, which may be an additional risk factor for blood stasis, considering that these retirees, for the most part, have more idle time or inactivity. Professions or conditions in which there is little locomobility, for a long period of time, become a risk factor for the development of increased venous pressure in the lower limbs, leading to the emergence and chronicity of vasculogenic ulcers.

In terms of age, patients were equally divided between adults and the elderly. The advancing age makes people increasingly vulnerable to developing lesions, as physiological changes resulting from nutritional, metabolic, vascular and immune changes that affect circulation, vessel pressure and consequently the skin are more common in this phase of life. In addition to other peculiarities of the elderly, such as impaired mobility, altered cognitive pattern and comorbidities. These characteristics make the elderly person more susceptible to cardiovascular diseases, besides causing implications and prolonged hospitalizations (BUSO et al, 2016; MORAES et al, 2012).
In view of this, due to the aging of the population, it is essential that the elderly leave the position of liability and become a social protagonist with active habits of life. Policies that motivate healthy aging are fundamental in this process. Healthy aging is attributed to a broader conceptualization than the absence of disease, taking into account a process of adaptation to changes that happens throughout life, which allows the elderly to maintain their mental and social wellbeing (VALER et al, 2015).

The patients in this study were brown, which diverges from a study in which a higher prevalence of white skin patients was observed (BORGHARDT et al, 2016). This characteristic can be justified by the region of the study, Northeastern Brazil, where the brown population predominates, due to the characteristics of the region's own colonization, which translates traces of a mixed population.

It was also verified that the venous ulcer was associated more to the black and white colors and the arteriovenous ulcer to the yellow color (Chinese). Studies have shown an important relationship between black color and SAH. Considering that SAH is a risk factor for vascular pathologies, the relationship can be explained. As to the exteriorization of the lesion to the skin, it is observed that the white skin is more vulnerable in claiming its histological peculiarities, less melanin protection, thinner skin thickness and inferior in amount of collagen fibers (NOBLAT; LOPES;LOPES, 2004; CHAVAGLIA et al, 2015). No explanatory evidence was found in the literature for the association between yellow patients and arteriovenous ulcers.

Regarding the clinical profile, the majority of the patients had a medical diagnosis of peripheral angiopathy, being shown an association of this with the venous ulcers. Several pathologies can lead to chronic lesions in the lower limbs, including venous, arterial, traumatic, infectious and diabetic pathologies $^{19}$. Angiopathy (peripheral vascular disease) refers to minor trauma, which triggers pain and ischemia in the affected limb(AGUIAR JÚNIOR et al, 2015; CHAVAGLIA et al, 2015). Cardiovascular diseases, including peripheral angiopathy, occupy the leading causes of death in countries with high levels of socioeconomic development, due to the increase of life expectancy of the population (TOUZARD; PENA; COOK, 1995).

Patients with vasculogenic lesions presented SAH and DM, simultaneously or alone. At the present time, chronic noncommunicable diseases are 
a major concern in the area of Public Health in developing countries, since they increase the risk for the development of ulcers with consequences of scarring delay and / or amputation (TORRES et al, 2009; MATA; PORTO; FIRMINO, 2011). DM is associated with increased morbidity and mortality, and studies24 show that ulcerations affect on average $15 \%$ of patients with DM throughout their lives and the therapeutic resources for these lesions are complex, especially those with greater depth and more incapacitating(CARVALHO; SILVA, 2016).

Justifying these findings, amputation was the most performed surgical procedure in the study patients. Among the main indications of amputation, the diabetic foot leads, followed by peripheral angiopathy, sensory-motor neuropathy and infections. It is known that diabetics are exposed to a risk of amputation 25 times greater than a healthy person. Patients usually seek medical attention when the lesions are already in advanced stages, requiring a radical surgical procedure, such as amputation, which has an important impact on their quality of life and substantial change in their routine (BARBOSA, 2014; ASSUMPÇÃO et al, 2009).

Among the implications that an amputation can cause it is from changes in lifestyle, even in self-esteem and permanent or temporary incapacity for work. In addition, it favors acute and chronic complications (ALMEIDA et al, 2013).

Regarding the classification of vasculogenic ulcers, as shown in the literature, a higher incidence of venous lesions was observed. A study of chronic lower limb ulcers revealed a similar incidence with a $56 \%$ venous etiology, followed by mixed etiology $26 \%$ and $18 \%$ arterial etiology (AFONSO et al, 2013).

\section{CONCLUSIONS}

Among the vasculogenic ulcers, the most prevalent was venous etiology, followed by arteriovenous and, finally, arterial, with the main cause being angiopathy (peripheral vascular disease), with a higher prevalence in the elderly male, data not confirmed by the literature, which predicts a higher incidence in women. The chronic diseases, SAH and DM, are the most common comorbidities in this population, and the most frequent surgical procedure was amputation, which causes a relevant emotional and social impact.

Vasculogenic ulcers represent a real public health problem, due to functional and psychological limitations to patients, as well as the structural and financial impact on health systems. Thus, a deeper approach on these patients is suggested, especially studies that work on the qualitative issue of the subject.

Among the limitations of this study, the difficulty in data acquisition is evidenced, which determined the size of the sample, due to the long hospitalizations, generating low turnover of patients in the field.

RESUMO: As Úlceras Vasculogênicas podem ser de origem arterial, venosa ou arteriovenosas (mistas) e comprometem a derme e epiderme, podendo afetar também tecidos mais profundos, caracterizado por um processo crônico, doloroso e de cicatrização lenta, o que gera impacto na qualidade de vida e nos aspectos mental, físico e social das pessoas acometidas, podendo assim levá-las à dependência total do serviço de saúde. Objetivou-se caracterizar o perfil sociodemográfico e clínico de pacientes com úlceras vasculogênicas. Trata-se de um estudo descritivo transversal desenvolvido na Clínica Cirúrgica em um Hospital de Urgência na região Nordeste do Brasil com 38 pacientes com úlceras vasculogênicas, no período de setembro a outubro de 2016. Os dados foramcoletados nos prontuários dos pacientes e confirmados mediante entrevista. Como resultado do perfil sociodemográfico, observou-se que a maioria era do sexo masculino $(55,3 \%)$, pardos $(55,3 \%)$, idosos e adultos $(50 \%$, cada) casados $(50 \%)$, com renda de até um salário mínimo $(81,6 \%)$, aposentados $(55,3 \%)$, cursaram no máximo o ensino fundamental $(57,9 \%)$ e todos eram da região Nordeste do Brasil. Clinicamente, 34,2\% apresentaram angiopatia periférica, úlceras venosas (50\%), Hipertensão Arterial e Diabetes Melitus (50\%). O procedimento cirúrgico mais realizado foi a amputação foi o do membro afetado pela úlcera $(55,3 \%)$. Conhecer o perfil da clientela é fundamental para a tomada de decisões mais acertadas e a definição de um raciocínio clínico mais condizente com os pacientes, que devem ser conduzidos de maneira integral pela equipe de enfermagem.

PALAVRAS-CHAVE: Úlceras vasculogenicas. Feridas. Enfermagem.

\section{REFERENCES}


AGUIAR JÚNIOR, A. C. A. et al. Analysis of the clinical care of patients with chronic ulcers of the lower limbs. Rev. Bras. Cir. Plást. v. 30, n. 2, p. 258-263, 2015.

AFONSO, A. et al. Úlcera crónica do membro inferior - experiência com cinqüenta doentes. Angiol Cir Vasc. v. 9, n. 4, p. 148-153, 2013. https://doi.org/10.1016/S1646-706X(13)70035-1

ALMEIDA, S. A. et al. Avaliação da qualidade de vida em pacientes com diabetes mellitus e pé ulcerado. Rev Bras Cir Plást. v. 28, n. 1, p. 142-6, 2013. https://doi.org/10.1590/S1983-51752013000100024

ASSUMPÇÃO, E. C. et al. Comparação dos fatores de risco para amputações maiores e menores em pacientes diabéticos de um Programa de Saúde da Família. J Vasc Bras. by Sociedade Brasileira de Angiologia e de Cirurgia Vascular. v. 8, n. 2, p. 133-138, 2009. https://doi.org/10.1590/S1677-54492009000200006

BARBOSA, K. A. B. The use of etetrothermofototherapeutic resources in the treatment of diabetic ulcers: a literature review. Campina Grande-PB,2014.

BORGHARDT, A. T. et al. Pressure ulcers in critically ill patients: incidence and associated factors. Rev Bras Enferm. Brasília, v. 9, n. 3, p. 431-8, 2016.

BUSO, A. L. Z. et al. Perceptions of elderly living with leg ulcer= Percepções de idosos vivendo com úlceras de perna. Bioscience Journal, v. 32, n. 5, p. 1373-9, 2016. https://doi.org/10.14393/BJ-v32n1a2016-32738

CARDOZO, G. M. et. al. Contribuição da enfermagem para avaliação da qualidade de vida de pessoas com úlceras de perna. Revista Estima, v. 10, n. 2, p. 19-27, 2012.

CARVALHO, E. R.; SILVA, J. D. B. The importance of nursing care to the patient with diabetes mellitus: Bibliographic review. Revista Iniciare, v. 1, n. 1, p. 91-102, jul. /dez. 2016.

CHAVAGLIA, S. R. R. et al. Caracterização de pacientes com lesão cutânea em unidades de internação médica e cirúrgica. Rev enferm UFPE on line., v. 9, n. 1, jan., 2015.

DIAS, T. Y. A. F. et al. Avaliação da qualidade de vida de pacientes com e sem úlcera venosa. Rev. LatinoAm. Enfermagem. v. 22, n. 4, p. 576-81, jul.-ago. 2014.

FIGUEIREDO, M. L.; ZUFFI, F. B. Caring for patients with venous ulcer: perception of nurses in the Family Health Strategy. Enferm.glob. v. 11, n. 28, p. 137-46, 2012.

GONZÁLEZ-CONSUEGRA, R. V.; VERDÚ, J. Quality of life in people with venous leg ulcers: an integrative review. Journal of advanced nursing. v. 67, n. 5, p. 926-944, 2011. https://doi.org/10.1111/j.13652648.2010.05568.x

GRIEP, R. G.; CHOR, D.; FAERSTEIN, E. Validade de constructo de escala de apoio social do Medical. OutcomesStudyadaptada para o português no Estudo Pró-Saúde.Caderno de Saúde Pública. v. 21, n. 3, p. 703-714, 2005. https://doi.org/10.1590/S0102-311X2005000300004

LOPES, F. F. Project of assistance at the foot of the patient with diabetes mellitus. J Vasc Br. v. 2, n. 1, p. 7982, 2003.

MALAQUIAS, G. S et al. Pessoas com úlceras vasculogênicas em atendimento ambulatorial de enfermagem: estudo das variáveis clínicas e sociodemográficas. RevEscEnferm USP. v. 46, n. 2, p. 302-10, 2012.

MATA, V. E.; PORTO, F.; FIRMINO, F. Time and cost's procedury: ulcers vasculogenics curative's. R. pesq: cuid. fundam. online. v. 3, n. 1, p. 1628-37, 2011. 
MEDEIROS, A. B. A. et al. Association of socioeconomic factors and Clinics and the result of tissue integrityIn patients with ulcers. Rev Gaúcha Enferm.v. 37, n. 1, p. 1-9, 2016.

MORAES, G. L. A. et al. Avaliação de risco para úlcera por pressão em idosos acamados no domicílio. Acta Paul Enferm. v. 24 , n. 1, p. 7-12,2012. https://doi.org/10.1590/S0103-21002012000800002

NOBLAT, A. C. B; LOPES, M. B; LOPES, A. A. Raça e Lesão de Órgãos-Alvo da Hipertensão Arterial em Pacientes Atendidos em um Ambulatório Universitário de Referência na Cidade de Salvador. Arq Bras Cardiol, v. 82, n. 2, p. 111-5, 2004. https://doi.org/10.1590/S0066-782X2004000200002

OLIVEIRA, B. G. R. B. et al. Characterization of patients with venous ulcer accompanied at the Wound Repair Ambulatory. Rev. Eletr. Enf. v. 14, n. 1, p. 156-3, 2013.

O'DONNELL, T. F. JR.; LAU, J. A systematic review of randomized controlled trials of wound dressings for chronic venous ulcer. J Vasc Surg. v. 44, n. 5, p. 1118-25,2006. https://doi.org/10.1016/j.jvs.2006.08.004

SANT'ANA, S. M. S. C. et al. Úlceras venosas: caracterização clínica e tratamento em usuários atendidos em rede ambulatorial. Rev. bras. enferm. v. 65, n. 4,p. 637-644, 2012. https://doi.org/10.1590/S003471672012000400013

SILVA, D. S.; HANH, G. V. Cuidados com úlceras venosas: realidade do Brasil e Portugual. RevEnferm, v. 2, n. 2, p. 330-338, 2012 .

TEIXEIRA, A. K. S.; SILVA, L. F. Reflexão sobre o cuidado clínico de enfermagem à pessoa com úlcera venosa segundo a Teoria de Imogene King. Revista Estima, v. 13, n. 3, 2016.

TORRES, G. V. et al. Idosos com úlceras venosas atendidos nos níveis primário e terciário: caracterização sócio demográfica, de saúde e assistência. Rev Enferm. v. 3, n. 4, p. 222-30, 2009.

TOUZARD, M. E; PENA, Z. D; COOK, J. M. M. C. Angiopatías periféricas enlapoblación senil. Rev Cubana HigEpidemiol, Ciudad de la Habana, v. 33, n. 1, p. 9-10, jun. 1995

VALER, D. B. et al. The significance of healthy aging for older persons who participated in health education groups. Rev. Bras. Geriatr. Gerontol., v. 18, n. 4, p. 809-19, 2015. https://doi.org/10.1590/1809-

9823.2015.14042 